\title{
Plant and Microbial Growth Responses to Multi-Walled Carbon Nanotubes
}

\author{
Keita K, Okafor F*, Nyochembeng L, Overton A, Sripathi VR and Odutola J
}

Department of Biological and Environmental Sciences, Alabama A\&M University, Alabama, USA

${ }^{*}$ Corresponding author: Okafor F, Department of Biological and Environmental Sciences, Alabama A\&M University, Alabama, USA, Tel: 256-372-4422; E-mail: florence.okafor@aamu.edu

Received date: May 8, 2018; Accepted date: May 23, 2018; Published date: May 30, 2018

Copyright: ( 2018 Keita K, et al. This is an open-access article distributed under the terms of the Creative Commons Attribution License, which permits unrestricted use, distribution, and reproduction in any medium, provided the original author and source are credited.

\begin{abstract}
Carbon nanotubes, made of graphene, one of the world's strongest material, has shown properties that are used in applications such as energy storage devices, electron emission devices, and environmental engineering application. Recently, researchers have focused on determining the effects of carbon nanotubes on soil microorganisms and plants.
\end{abstract}

Objective: The purpose of this study was to determine if the multi-walled carbon nanotubes will affect the growth of Phaseolus vulgaris as well as inhibit the growth of select soil microbes.

Methods: The effects of Multi-Walled Carbon Nanotubes were determined on bean plants grown under hydroponic conditions and on select soil microbes. Two weeks after germination, the plants were exposed to different concentrations of dispersed multi-walled carbon. The different concentrations were $0 \mathrm{ug}$ (control), $50 \mu \mathrm{g}$, $250 \mu \mathrm{g}, 500 \mu \mathrm{g}, 750 \mu \mathrm{g}$ and $1000 \mu \mathrm{g} \mathrm{mL}-1$. The growth was reported weekly by measuring the plants themselves, the diameter of the leaf, length and width, the roots, and the fruits. Cultures of Mesorhizobium sp. and Nitrosomonas stercoris were exposed to the $0 \mu \mathrm{g}$ (control), $50 \mu \mathrm{g}, 250 \mu \mathrm{g}, 500 \mu \mathrm{g}, 750 \mu \mathrm{g}$ and $1000 \mu \mathrm{g} \mathrm{mL}{ }^{-1}$ of dispersed MWCNTs then incubated in the BioScreen reader. The optical density was reported every 30 minutes for 24 hours.

Results: Our results showed that at $50 \mu \mathrm{g} / \mathrm{mL}$, bean plants exhibited tolerance to the multi-walled carbon nanotubes whereas at $250 \mu \mathrm{g} / \mathrm{mL}$ and $500 \mu \mathrm{g} / \mathrm{mL}$ of MWCNTs plants showed reduced growth and development and even plant death. Aliquots of $750 \mu \mathrm{g} / \mathrm{mL}$ and above of MWCNTs lowered the microbial biomass. The presence of high concentrations of carbon nanotubes is likely to cause stress to microbes and the direct contact of CNTs with microbes could damage their cell membrane leading to cell death.

Conclusion: As results of this study, the concentration of multi-walled carbon nanotubes should be set at a maximum of $500 \mathrm{\mu g} \mathrm{mL}^{-1}$ when being released to the soil or environment.

Keywords: Multi-Walled Carbon Nanotubes; Graphene; Nanomaterials; Phaseolus vulgaris; Bush Bean; Mesorhizobium sp; Nitrosomonas stercoris

\section{Introduction}

Nanotechnology cuts across all science fields (chemistry, biology, physics, materials science, and engineering). This growing field has become a key empowering innovative tool in the industry because of its high application abilities. It is now utilized as a part of electronic, health services, chemical, beauty care products, composites and energy [1].

Nanoparticles (also known as inorganic materials), the most fundamental component in the production of a nanostructure, are particles with a nominal diameter (such as geometric, aerodynamic, mobility, projected-area or otherwise) less than one hundred nanometers [1]. They are also defined as a sub-classification of ultrafine particles with the size range of about 1-100 $\mathrm{nm}$ [2].

Many properties and applications of nanotechnology have been discovered recently which are contributing to major changes in the global economy. In medicine, the applications of nanotechnology are used to detect and treat human body diseases at cellular levels. In electronics, nanomaterials are used to display screens by reducing the power consumption, weight, and thickness of the screens, therefore making it less expensive. Nanomaterials are used in fuel cells, solar cells, batteries, and spacecraft, to limit the carbon emission, to enhance air quality, to produce cleaner water, chemical sensors, in fabrics and sporting goods. In food science, nanotechnology is developing materials such as Nano food packaging materials that may extend food shelf-life, improve food safety, alert consumers that food is contaminated or spoiled, repair tears in packaging, and even release preservatives to extend the life of the food in the package [3]. For example, clay nanoparticles are used to provide impermeability to gases such as oxygen and carbon dioxide. Silicate nanoparticle is used as a barrier to gases to prevent food from spoiling or drying. Carbon nanotubes can be used as chemical and mechanical sensors because of their small size. Also, carbon nanotubes are used in Smart packaging (plastic food wrap) as gas sensors that could enhance food safety and reduce the amount of food that is wasted [4]. Silver nanoparticles are now used in agriculture because of its property of killing pathogenic 
bacteria. Zinc oxide nanoparticles are used in packaging as a barrier against UV rays as well as anti-bacterial protection.

Carbon nanotubes were discovered in 1991 by Sumio Iijima [5]. They are cylindrical in structure and are allotropes of carbon (one of two or more existing forms of carbon). Allotropes of carbon can be presented in different structures (diamond, graphite, and carbon nanotubes) (Figure 1). Carbon nanotubes are available in powder (Figure 2) and in two types: single wall carbon nanotube (SWCNT) and multi-wall carbon nanotube (MWCNT) (Figure 3).

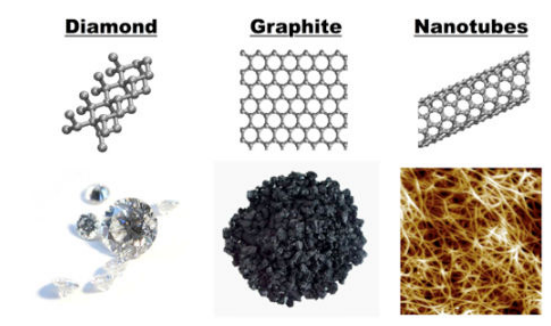

Figure 1: Forms of Carbon allotropes [6].

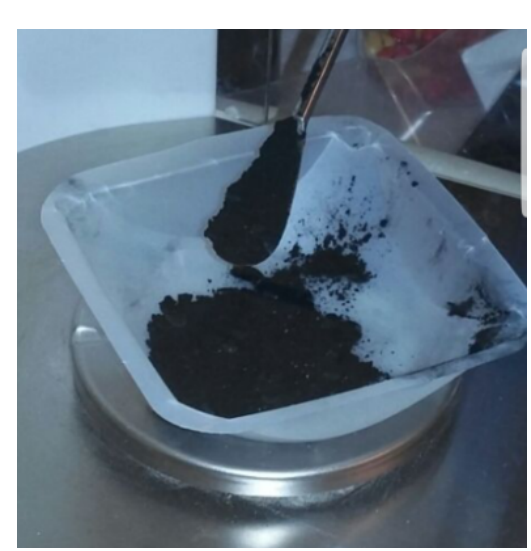

Figure 2: Powder of carbon nanotubes.

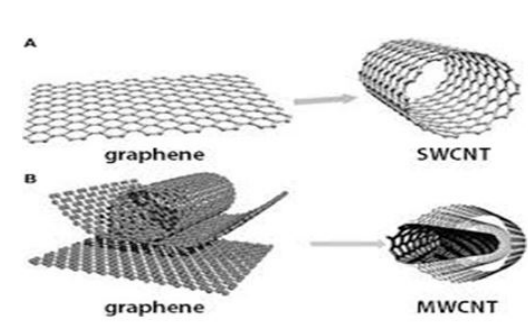

Figure 3: Graphene and carbon nanotubes as (A) single wall carbon nanotube (SWCNT) (B) multi-wall carbon nanotube (MWCNT) structures $[7,8]$.

As the nanomaterials are in high demand in today's society, their use in industry is increasing. Therefore, this increase will result in the release of nanoparticles to the environment [9]. Kerfahi et al. in 2015 reported that global carbon nanotubes (CNT) production increased by around $25 \%$ every year and reached 9300 tons with a production value of $\$ 1.3$ billion [10]. In 2013, Shrestha et al. also reported that since there are no strict rules regulating CNTs production, usage, and disposal, substantial quantities of CNTs could bind to pollutants such as heavy metals and be released into the environment with the potential to affect the environment and human health [11].

Very few studies have been addressed on the effects of carbon nanotubes on living organisms in the environment. Carbon nanotubes have demonstrated toxicity to several organisms, such as protozoa (Stylonychia mytilus), copepods, mice, and rainbow trout (Oncorhynchus mykiss), but very little, however, is known about the toxicity of these nanomaterials to plants and plant parts [12-13]. Furthermore, Kang et al. in 2007 demonstrated that the contact of carbon nanotubes with Escherichia coli may kill the bacteria [14]. Further research is needed to determine whether carbon nanotubes are harmful to plants, and the soil microorganisms [15-16].

There is a controversy regarding the toxicity of carbon nanotubes to humans because of the differences in experimental procedures. Kerfahi et al. in 2015 mentioned that the toxicity of the carbon nanotubes has been studied in vivo and in vitro and related to various factors as length, type of functionalization, concentration, duration of exposure, the method of exposure, the concentration of the solubilizing agent, and the surfactant used [17]. Mukherjee et al. reported that the toxicity of carbon nanomaterials on plants depends on the concentrations, growth/exposure conditions, and plant species [18]. The purpose of this study was to determine if the multi-walled carbon nanotubes will affect the growth of bean plants as well as inhibit the growth of select soil microbes.

In this study, the commercial multi-walled carbon nanotubes were used because of their low cost and their easiness to be massively produced compared to the single-walled carbon nanotubes [19]. Phaseolus vulgaris (Bush beans) plants will be grown under hydroponic conditions, since to our knowledge, no study has been done to determine the effects of carbon nanotubes on Bush beans. The reason for choosing bush bean is because of its economic and nutritional importance, and it is easy to grow [20].

Bush beans are among the most ancient crops of the world. They are the most important grain legumes for human consumption in the world. Total production of beans exceeds 23 million Metric Tons (MT), of which seven million MT is produced mainly in Latin America and Africa [21]. Green beans have very low calories and very rich source of dietary fiber. They also contain elevated levels of vitamin A promoting flavonoid, poly phenolic antioxidants such as lutein, zeaxanthin and $\tilde{A} \ddot{Y}$-carotene in good amounts, vitamin B such as B1 and B6, vitamin $\mathrm{C}$, and minerals such as iron, calcium, $\mathrm{MgMn}$ and potassium.

\section{Review of Literature}

Many studies have been done to determine the effect of carbon nanotubes on soil microorganisms and plants. The application of carbon nanotubes to the soil can decrease the soil enzymatic activities and the microbial biomass. Chung et al. in 2011 exposed two types of soils that have distinct soil physico-chemical properties (one with grasses, and the other with coniferous trees) to $5000 \mu \mathrm{g}$ of multi-walled carbon nanotubes (MWCNTs). They demonstrated that at $5000 \mu \mathrm{g}$ MWCNTs $\mathrm{g}^{-1}$ of soil, the activities of 1,4-b-glucosidase, cellobiohydrolase, xylosidase, 1,4-b-N-acetylglucosaminidase, and phosphatase decreased as well as the microbial biomass $\mathrm{C}$ and $\mathrm{N}$ measured at 20 days [22]. Jin et al. exposed a soil sample to both 
suspended and powder single-walled carbon nanotube at concentrations from $0-1000 \mu \mathrm{g} \mathrm{g}^{-1}$ soil, incubated for three weeks [23]. They also demonstrated that single-walled carbon nanotubes (SWCNTs) at 300-1000 $\mu \mathrm{g} \mathrm{g}^{-1}$ could significantly decrease the activities of enzymes such as cellobiohydrolase, $\beta$-1, 4-glucosidase, $\beta$-1, 4xylosidase, $\beta-1$, 4-N-acetylglucosaminidase, L-leucine aminopeptidase and acid phosphatase, and microbial biomass. In 2014, Jin et al. incubated soil sample to $0,0.03,0.1,0.3,0.6$ and $1 \mathrm{mg} \mathrm{g}^{-1}$ soil of singlewalled carbon nanotubes for 25 days. They demonstrated that these concentrations of SWCNT significantly affected soil phospholipid fatty acid (PLFA) profiles. They also demonstrated that SWCNTs has a significant negative relationship with the biomass of a broad range of microbial groups including Gram-positive and Gram-negative bacteria, and fungi [24]. Furthermore, Kang et al. in 2007 demonstrated that highly purified single-walled carbon nanotubes (SWNTs) exhibit strong antimicrobial activity. E. coli K12 was exposed to SWCNTs ( 1 to $50 \mu \mathrm{g} \mathrm{mL} \mathrm{m}^{-1}$ of aqueous solution) for $60 \mathrm{~min}$; then the viability was tested using a fluorescence-based assay. The result showed that cells incubated with SWNTs exhibited a substantial loss in viability. It demonstrated that cell membrane damage resulting from direct contact with SWNT aggregates is the mechanism leading to bacterial cell death [14].

Studies also show that soil microbial communities may not always be affected when in contact with carbon nanotubes or may develop resistance when exposed to high concentrations of these nanotubes. In 2009, Kang et al. even applying a high concentration of nanotubes, did not find significant effects on soil bacterial communities [25]. Khodakovskaya et al. in 2013 also show that species diversity and richness of microbial communities were not affected by multi-walled carbon nanotubes, while the abundance of each bacterial group was influenced by treatment of CNTs [26]. Kerfahi et al. in 2015 conducted a study by comparing the effect of both raw and functionalized multiwalled carbon nanotubes (MWCNTs) on soil bacterial communities. Different concentrations $\left(0 \mu \mathrm{g} g^{-1}, 50 \mu \mathrm{g} g^{-1}, 500 \mu \mathrm{g} g^{-1}\right.$ and $\left.5000 \mu \mathrm{g} g^{-1}\right)$ of MWCNTs were applied to a soil microcosm system. The DNA extracted and amplified showed that the bacterial diversity was not affected by either type of MWCNTs, the soil bacterial community composition was affected only by the functionalized MWCNTs at high concentrations [10]. However, Shrestha et al. in 2013 evaluated the impacts of different concentrations of multi-walled carbon nanotubes (10 $\mathrm{mg} \mathrm{kg}^{-1}-10,000 \mathrm{mg} \mathrm{g}^{-}$) on microbial community composition in sandy loam soil for 90 days. Two reactions were observed: a decreased abundance of some bacterial genera such as Derxia, Holophaga, Opitutus and Waddlia at the highest concentration and an increase in the population of bacterial genera (Rhodococcus, Cellulomonas, Nocardioides, and Pseudomonas) considered potential degraders of recalcitrant contaminants (such as polycyclic aromatic hydrocarbons). Thus, suggesting a shift in soil microbial community composition to more tolerant microbial populations in the presence of extremely high MWCNT concentrations [11].

The absorption of carbon nanotubes by plants can change the plant metabolic system by affecting the biomass, fruits, and roots. Husen and Siddiqi in 2014 demonstrated that carbon nanotubes could penetrate the seed coat and plant cell wall. This penetration of carbon nanotubes into the plant system cause bring changes in metabolic functions leading to an increase in biomass, fruit/grain yield [27]. Also, singlewalled carbon nanotubes passively transport and localize within the lipid envelope of extracted plant chloroplasts, promote more than three times higher photosynthetic activity than the ones that have not received any treatment of single-walled carbon nanotubes and enhance maximum electron transport rates [28]. Miralles et al. in 2012 exposed two crop species (alfalfa and wheat) to multi-walled CNTs at concentrations of 40-2560 $\mathrm{mg} \mathrm{l}^{-1} \mathrm{DI}$ water, these plants tolerated high concentrations of MWCNTs, and even enhanced root elongation in alfalfa seedlings as well as wheat germination in their presence [29]. Tomato plants, grown in soil supplemented with $50 \mu \mathrm{g} \mathrm{mL}{ }^{-1}$ and $200 \mu \mathrm{g}$ $\mathrm{mL}^{-1}$ of carbon nanotubes, produced twice more flowers and fruits than the ones grown in regular soil even if they produced the same amount of leaves [26]. Furthermore, Srivastava and Rao in 2014 have also demonstrated that multi-walled carbon nanotubes significantly enhance plant growth and biomass on wheat, maize, peanut, and garlic. They were able to prove that seeds exposed to MWCNTs sprouted up to three to four times faster than the control group, and the presence of carbon nanotubes on peanut root shows an enhanced water delivery [30]. However, Ratnikova et al. in 2015 conducted a study on tomatoes by testing the tomato seed coat permeability contrasts this finding. The seeds were soaked into $50 \mathrm{mg} \mathrm{L}^{-1}$ of carbonbased nanomaterials (fullerol and multi-walled nanotubes) for 0 to 60 minutes. The penetration of seed coats to the embryo by the carbonbased nanomaterials (CBNMs), as well as CBNMs effects on seed germination and seedling growth, was examined. This study found that neither of the CBNMs was able to penetrate tomato seed coats [31].

While some plants grow faster when exposed to carbon nanotubes, other plants show inhibition, or the carbon nanotubes do not show effects on the plants. In 2012, Khodakovskaya et al. studied the effects of multi-walled carbon nanotubes at concentrations of 5-500 $\mu \mathrm{g} \mathrm{mL}^{-1}$ on tobacco seed germination and demonstrated that multi-walled carbon nanotubes have the ability to enhance the growth of tobacco cell culture by $55-64 \%$. However, they proved that activated carbon stimulated cell growth only at low concentrations $\left(5 \mu \mathrm{g} \mathrm{mL}{ }^{-}\right)$while dramatically inhibited the cellular growth at higher concentrations (100-500 $\left.\mu \mathrm{g} \mathrm{mL}^{-1}\right)$ [32]. Canas et al. in 2009 show that tomato, onion and cucumber plants grow well when exposed to both functionalized and non-functionalized carbon nanotubes while an inhibition on the root elongation of lettuce and no effects on the root elongation of cabbage and carrot were observed [16]. Stampoulis et al. in 2009 tested the effect of MWCNTs on zucchini under hydroponic conditions for 15 days. They observed a $60 \%$ reduction in biomass when compared to control and bulk carbon at $1000 \mathrm{mg} \mathrm{mL}^{-1}$ [33].

\section{Materials and Method}

\section{Nanotubes preparation}

The multi-walled carbon nanotubes (MWCNTs) - $\mathrm{COOH}$ functionalized, purchased from Skyspring Nanomaterials Inc., USA, were dissolved in 1X Phosphate-buffered saline which is a buffer solution commonly used in biological research [34]. It is isotonic, nontoxic to cells, mostly used as a diluent for substances and $1 \%$ of Dimethyl Sulfoxide (DMSO), known to enhance the rate of absorption of compounds, has biological properties, and has been shown that the suspensions prepared with the dispersed carbon nanotubes exhibit a long-lasting stability [35].

The functionalization of carbon nanotubes produces useful gatherings at the surfaces of carbon nanotubes which could respond with chemicals, pre-polymers, and polymers. It is a strategy used to improve the interfacial bond between the matrix and carbon nanotubes for their future application to polymer nanocomposites [36]. Chemical functionalization of carbon nanotubes depends on the covalent groups $(-\mathrm{OH},-\mathrm{COOH})$ onto carbon type of CNTs. It can be 
performed toward the end tops of nanotubes or at their sidewalls which have numerous imperfections [37]. The characteristics of multiwalled carbon nanotubes are listed in the Table 1. A solution of the nanotubes was dispersed by ultrasonic vibration using a Sonicator from Branson Ultrasonics Corp (Model: Branson 3510 DTH, tank capacity $5.7 \mathrm{~L}$, digital timer/heater/degas/temp, AC input $115 \mathrm{~V}$ ).

\begin{tabular}{|l|l|}
\hline \multicolumn{2}{|l|}{ Multi-walled nanotubes (MWNTs) } \\
\hline Characteristics & Quantity \\
\hline Form & Powder \\
\hline Purity & $>95 \mathrm{wt} . \%$ \\
\hline Content of -COOH & $\sim 2.0 \mathrm{wt} \%$ \\
\hline Outside diameter & $10-20 \mathrm{~nm}$ \\
\hline Inside diameter & $3-5 \mathrm{~nm}$ \\
\hline Length & $5-30 \mathrm{um}$ \\
\hline Special Surface Area & $>350 \mathrm{~m}^{2} / \mathrm{g}$ \\
\hline SSA) & $<1.0 \mathrm{wt} . \%$ \\
\hline Ash & $<3.0 \%$ \\
\hline Amorphous carbon & $>100 \mathrm{~s} / \mathrm{cm}^{\circ}$ \\
\hline Electrical conductivity & $0.27 \mathrm{~g} / \mathrm{cm}^{3}$ \\
\hline Bulk density & $\sim 2.1 \mathrm{~g} / \mathrm{cm}^{3}$ \\
\hline True density & Catalytic Chemical Vapor Decomposition (CVD) \\
\hline Manufacturing method & \\
\hline
\end{tabular}

Table 1: Characteristics of the multi-walled carbon nanotubes.

\section{Growth of experimental plants}

Seeds germination: In this study, the leguminous bush bean was grown under hydroponic conditions using organic cocotek media purchased from Zen Hydro, located in California, USA. According to the manufacturer, the General Hydroponics Cocotek Organic Growing Medium has a balanced $\mathrm{pH}$, contains low sodium and is made up of natural coconut coir fiber. In addition, it has the property to increase water holding and nutrient retention for an extended period. The seeds of the bush beans were purchased from a local market, washed with deionized water and introduced into the Cocotek media, distributed into pots (Figure 4).

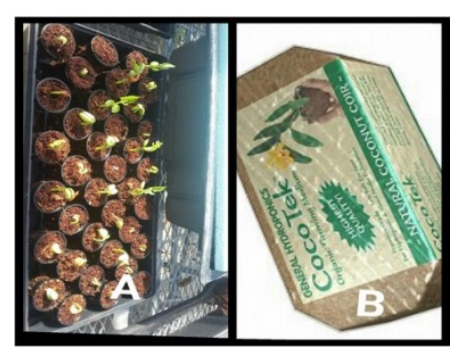

Figure 4: General hydroponics cocotek media A) Brick form B) Expanded form.
Plant exposure: Two weeks after germination, the plants were exposed to different concentrations of dispersed multi-walled carbon. The different concentrations were $0 \mu \mathrm{g}$ (control), $50 \mu \mathrm{g}, 250 \mu \mathrm{g}, 500 \mu \mathrm{g}$, $750 \mu \mathrm{g}$ and $1000 \mu \mathrm{g} \mathrm{mL}{ }^{-1}$. A balanced fertilizer Miracle Grow (N-P-K ratio: 24-8-16), purchased from a local market was added once a month. The plants were monitored daily, but the growth was reported weekly by measuring the plants themselves, the diameter of the leaf, length and width, the roots, and the fruits. The $\mathrm{pH}$ of the hydroponic water, temperature, and humidity of the greenhouse were also monitored. In addition, gram ve+, gram ve- bacteria as well as Fungi were isolated and identified from the hydroponic water. After fruiting, the bean plant biomass was collected, dried and tested to determine the percent by weight of Carbon, Hydrogen, and Nitrogen.

\section{Antimicrobial activity of MWCNTs}

Cultures of Mesorhizobium sp. and Nitrosomonas stercoris were purchased from American Type Culture Collection (ATCC, Manassas VA, USA) then grown in Brain-Heart Infusion (BHI) for 48 hours respectively at $37^{\circ} \mathrm{C}$ and $30^{\circ} \mathrm{C}$ according to the instructions from ATCC. These bacteria were chosen because of their specific properties in carbon cycling, importance in soil fertility and plant growth. These bacteria were diluted using the McFarland $\mathrm{n} .5$ as standard then exposed to the $0 \mu \mathrm{g}$ (control), $50 \mu \mathrm{g}, 250 \mu \mathrm{g}, 500 \mu \mathrm{g}, 750 \mu \mathrm{g}$ and 1000 $\mu \mathrm{g} \mathrm{mL} \mathrm{mL}^{-1}$ of dispersed MWCNTs then incubated for 24 hours in the BioScreen. For this experiment, a total of $125 \mu \mathrm{L}$ were loaded in the microplates with $115 \mu \mathrm{L}$ of the bacterial suspension and $10 \mu \mathrm{L}$ of dispersed MWCNTs, and $120 \mu L$ of diluted bacteria and $5 \mu L$ of $M W C N T s$. The experiment was replicated twice and repeated three times to confirm our results. The optical density was reported every 30 minutes.

Data collected from our study were analyzed using the GLM Procedure of Statistical Analysis System (SAS, version 9.4) software (SAS Institute Inc., Cary NC, USA). Treatment means were separated and compared using LSD mean separation at 5\% significance level.

\section{Results}

\section{Plant growth results (Table 2)}

\begin{tabular}{|c|c|c|c|c|}
\hline \multicolumn{5}{|c|}{ Germination rate of the Seeds $\mathbf{8 0} \%$} \\
\hline $\begin{array}{l}\text { Concentrat } \\
\text { ion of } \\
\text { MWCNTs }\end{array}$ & $\begin{array}{l}\text { Number of } \\
\text { Plants per tray } \\
\text { before exposure }\end{array}$ & $\begin{array}{l}\text { Number of } \\
\text { Plants per tray } \\
\text { after exposure }\end{array}$ & $\begin{array}{l}\text { Number of } \\
\text { Pods after } \\
\text { harvest }\end{array}$ & $\begin{array}{l}\text { Survival } \\
\text { Rate after } \\
\text { exposure } \\
(\%)\end{array}$ \\
\hline $0 \mu \mathrm{g}$ & 45 & 38 & 42 & 84.4 \\
\hline $50 \mu \mathrm{g}$ & 45 & 26 & 25 & 57.7 \\
\hline $250 \mu \mathrm{g}$ & 45 & 20 & 18 & 44.4 \\
\hline $500 \mu \mathrm{g}$ & 45 & 15 & 12 & 33.3 \\
\hline $750 \mu \mathrm{g}$ & 45 & 18 & 14 & 40 \\
\hline $1000 \mu g$ & 45 & 18 & 22 & 40 \\
\hline
\end{tabular}

Table 2: Number of Plants before and after exposure to MWCNTs.

All of our plants produced pods at the 4th week after exposure (Figure 5). At the 5th week after exposure, the plants were harvested. The effects of MWCNTs were observed in pods collected from plants 
Citation: Keita K, Okafor F, Nyochembeng L, Overton A, Sripathi VR, et al. (2018) Plant and Microbial Growth Responses to Multi-Walled Carbon Nanotubes . J Nanosci Curr Res 3: 123. doi:10.4172/2572-0813.1000123

Page 5 of 7

treated with $250 \mu \mathrm{g} \mathrm{mL}^{-1}$ to $1000 \mu \mathrm{g} \mathrm{mL}^{-1}$. The pods from these groups were either smaller or had different intensities of greening than the control group (Figure 6). Inhibition of the root elongation was observed in all of the treatments, especially at $500 \mu \mathrm{g} \mathrm{mL}^{-1}$ with an average length $9.88 \mathrm{~cm}$ compared to $20.6 \mathrm{~cm}$ in the control group (Figure 7).

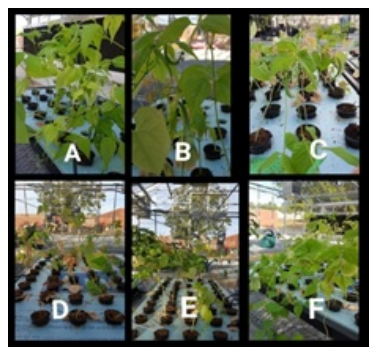

Figure 5: Mature beans at 4th week after exposure A) control B) 50 $\mu \mathrm{g}$, C) $250 \mu \mathrm{g}$ D) $500 \mu \mathrm{g}$ E) $750 \mu \mathrm{g}$ F) $1000 \mu \mathrm{g}$.

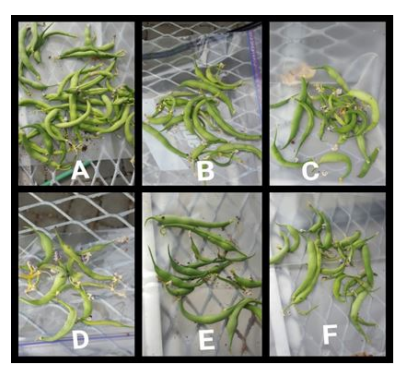

Figure 6: Fruits after harvest (4th week after exposure) A) control B) $50 \mu \mathrm{g}$ C) $250 \mu \mathrm{g}$ D) $500 \mu \mathrm{g}$ E) $750 \mu \mathrm{g}$ F) $1000 \mu \mathrm{g}$.

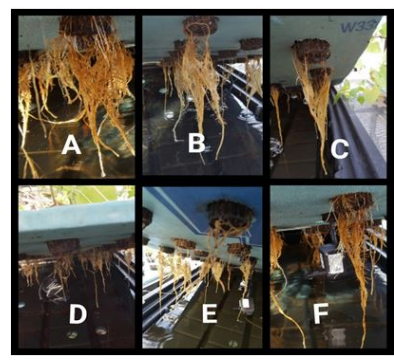

Figure 7: Roots of mature beans A) control B) $50 \mu \mathrm{g}$ C) $250 \mu \mathrm{g}$ D) $500 \mu \mathrm{g}$ E) $750 \mu \mathrm{g}$ F) $1000 \mu \mathrm{g}$.

After harvest, the stem and roots were collected, dried and weighed. The table below represents the dried weight of the root biomass after the harvest (Table 3).

\begin{tabular}{|l|l|l|l|l|l|l|}
\hline $\begin{array}{l}\text { Concentrations of } \\
\text { MWCNTs } \mathbf{~} \mathbf{g ~ m L}^{-1}\end{array}$ & $\mathbf{0}$ & $\mathbf{5 0}$ & $\mathbf{2 5 0}$ & $\mathbf{5 0 0}$ & $\mathbf{7 5 0}$ & $\mathbf{1 0 0 0}$ \\
\hline $\begin{array}{l}\text { Weight of the } \\
\text { stem (g) }\end{array}$ & 25 & 18.9 & 9 & 5.2 & 9 & 10.3 \\
\hline
\end{tabular}

\begin{tabular}{|l|l|l|l|l|l|l|}
\hline $\begin{array}{l}\text { Weight of the } \\
\text { roots (g) }\end{array}$ & 4.5 & 4.35 & 2.1 & 1.95 & 2.69 & 3.34 \\
\hline
\end{tabular}

Table 3: Dry weight of the roots and stems after harvest.

The \% CHN analysis of the roots did not show significant changes of carbon and Hydrogen when the concentration of MWCNTs increased. However, the percentage of Nitrogen slightly decreased (Table 4).

The statistical analysis indicated significant differences between the concentrations for shoot length of the plants exposed to 500, 750 and $1000 \mu \mathrm{g} \mathrm{mL}^{-1}(\mathrm{~F}=10.76, \mathrm{P}=0.0094)$. Significant differences were also observed between the MWCNT concentrations for leaf length $(\mathrm{F}=21.88, \quad \mathrm{P}=0.0018)$ and leaf width $(\mathrm{F}=7.81, \mathrm{P}=0.0189)$ when compared to the control group. Only the $500 \mu \mathrm{g} \mathrm{mL}-1$ group shows significant difference with the root length $(\mathrm{F}=6.51, \mathrm{P}=0.0279)$. Differences were also significant with the plants' survival rate on the $250 \mu \mathrm{g}, 500 \mu \mathrm{g}, 750 \mu \mathrm{g}$ and $1000 \mu \mathrm{g} \mathrm{mL}{ }^{-1}$ groups $(\mathrm{F}=6.40, \mathrm{P}=0.0288)$. (shown in supplementary file)

\begin{tabular}{|l|l|l|l|}
\hline Samples & \% C & $\% \mathrm{H}$ & $\% \mathbf{~ N}$ \\
\hline Control & 43.97 & 5.05 & 3.11 \\
\hline $50 \mu \mathrm{g} \mathrm{m}^{-1}$ & 44.48 & 5.39 & 2.29 \\
\hline $250 \mu \mathrm{g} \mathrm{mL}^{-1}$ & 43.04 & 5.15 & 2.38 \\
\hline $500 \mu \mathrm{g} \mathrm{mL}^{-1}$ & 43.82 & 5.4 & 2.39 \\
\hline $750 \mu \mathrm{g} \mathrm{mL}^{-1}$ & 44.24 & 5.26 & 2.78 \\
\hline $1000 \mu \mathrm{g} \mathrm{mL}^{-1}$ & 45.1 & 5.39 & 2.75 \\
\hline
\end{tabular}

Table 4: Percentage of Carbon, Hydrogen, and Nitrogen from the roots.

\section{Antimicrobial activities of MWCNTS}

The observations were similar when the microbes were exposed to both $10 \mu \mathrm{L}$ and $5 \mu \mathrm{L}$ of $M W C N T s$. The statistical analysis did not show significant differences when the bacteria were exposed at lower concentrations $\left(0-500 \mu \mathrm{g} \mathrm{mL}^{-1}\right)$ of MWCNTs. Therefore, the growth of the experimental bacteria was not inhibited. However, a significant inhibitory effect was observed ( $F=15.28$ and $p=0.001)$ when the bacteria were exposed to $750 \mu \mathrm{g} \mathrm{mL}^{-1}$ and $1000 \mu \mathrm{g} \mathrm{mL} \mathrm{m}^{-1}$ of $M W C N T s$ (Figures 8 and 9).

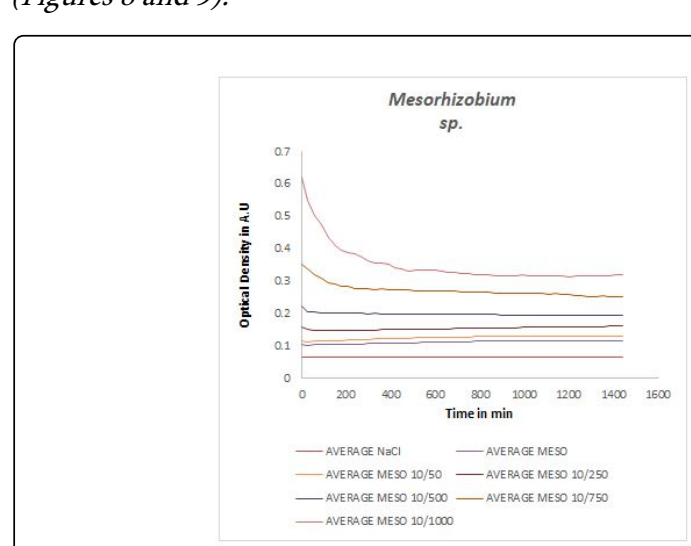

Figure 8: Culture of Mesorhizobium sp. exposed to different concentrations of multi-walled carbon nanotubes. 


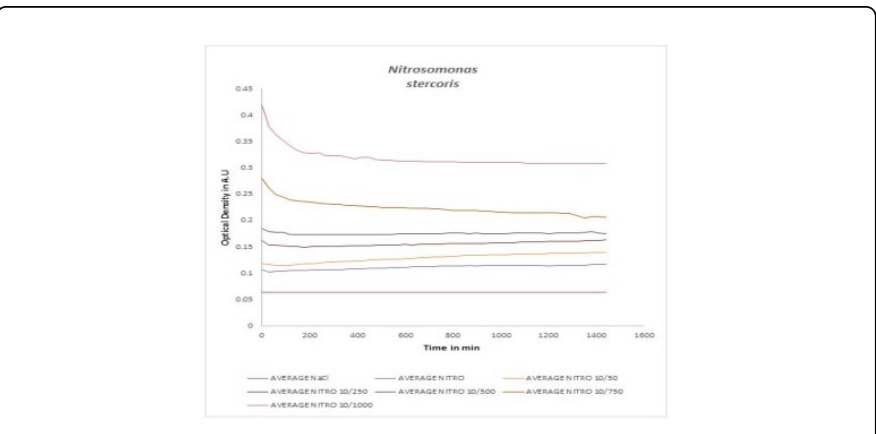

Figure 9: Culture of Nitrosomonas stercoris exposed to different concentrations of multi-walled carbon nanotubes.

\section{Discussion}

In our study, the effects of the accumulation of MWCNTs by the bean plants were determined based on their concentration. At a very low concentration $\left(50 \mu \mathrm{gL}^{-1}\right)$, bean plants tolerated the MWCNTs even though our plants showed a very low level of stress on their leaves. Exposure to high concentrations under hydroponic conditions may result in translocation of MWCNTs in the leaves, roots and even the fruits. These effects were highly observed on our plants exposed to $250 \mu \mathrm{g} \mathrm{mL}^{-1}, 500 \mu \mathrm{g} \mathrm{mL}^{-1}$ and $750 \mu \mathrm{g} \mathrm{mL}^{-1}$. The $500 \mu \mathrm{g} \mathrm{mL}^{-l}$ was our toxic concentration in all of our experiments. However, at $1000 \mu \mathrm{g}$, the high concentration of MWCNTs it is believed to form clumps preventing the roots of the plants from taking them up [29,39] and dramatically inhibiting the cellular growth [32]. The interaction of multiwall CNTs with the plant cells can result in significant changes in total gene expression and lead to the activation of many stress-related genes $[38,39]$ and can significantly inhibit the plant growth by decreasing the concentrations of endogenous plant hormones [40]. Additionally, our study demonstrates that the presence of MWCNTs is likely to decrease the root biomass which corroborated a study conducted by Begum et al. in 2000 [41].

The presence of nanotube sheets was previously detected under scanning electron microscopy on the root surfaces. However, the images did not show any possible uptake [16]. We also demonstrated that the absorption of MWCNTs does not affect the percentage of carbon and Hydrogen while the percentage Nitrogen decreased. This finding was previously confirmed in 2016 by Hao et al. [40] who stated that the presence of MWCNTs in the roots decreased the Nitrogen assimilation.

Furthermore, we were able to demonstrate that high concentrations of carbon nanotubes could lower soil microbial activity; this similar to what Kerfahi et al. [17] observed in 2015. It also reflects the conclusion reached by Chung et al. in 2011 who suggested that their study could be used as a guideline when regulating the release of MWCNTs [22]. According to these studies confirmed by our studies, the presence of high concentrations of carbon nanotubes is likely to cause stress to microorganisms [42,43]. Also, the direct contact of CNTs with microorganisms could damage their cell membrane leading to cell death [14].

At low concentration $\left(0-500 \mu \mathrm{g} \mathrm{m}^{-1}\right)$, the MWCNTs did not show inhibitory effects on our selected bacteria. Our results are similar to the observations of Shrestha et al. in 2013 who concluded that a low concentration of MWCNTs has no effects on soil microbial community composition [11].

\section{Conclusion}

Our study shows that carbon nanotubes inhibit the Phaseolus vulgaris growth. At a low concentration of $50 \mu \mathrm{g} \mathrm{mL} \mathrm{m}^{-1}$, no effects on plant growth were observed even though the plants did show signs of stress on the leaves. However, at $250 \mu \mathrm{g} \mathrm{mL}^{-1}$ to $500 \mu \mathrm{g} \mathrm{mL} \mathrm{m}^{-1}$, the carbon nanotubes showed deadly effects on the bean plants especially at $500 \mu \mathrm{g} \mathrm{mL}^{-1}$. From $750 \mu \mathrm{g} \mathrm{mL}^{-1}$, there is a possibility that the carbon nanotubes may have formed clusters, preventing them from being absorbed by the plant roots. On the other hand, the higher concentrations $\left(750 \mu \mathrm{g} \mathrm{mL}^{-1}\right.$ to $\left.1000 \mu \mathrm{g} \mathrm{mL}^{-1}\right)$ showed significant inhibition on the growth level of soil microbes. As results of this study, the concentration of multi-walled carbon nanotubes should be set at a maximum of $500 \mu \mathrm{g} \mathrm{mL}^{-1}$ when being released to the soil or environment.

\section{Acknowledgments}

This work is supported by Evans-Allen grant no. 200094-20116 XX-140/ALAX-011-0816 from the USDA National Institute of Food and Agriculture.

We acknowledge the support given by Dr. Lloyd Walker, Dr. Heather Howell, Dr. Irenus Tazisong, Dr. Jorge Vizcarra, Dr. Thilini D. Ranatunga, Dr. Michael Curley and Dr. Zhigang Xiao.

\section{References}

1. Tielas A, Gabriel B, Santos C, Gracia D, Alcorta J, et al. (2014) Nanomaterials Guide for the SUDOE space industry.

2. Horikoshi S, Serpone N (2013) Introduction to nanoparticles, microwaves in nanoparticle synthesis. 1st edn Wiley-VCH Verlag GmbH and Co. KGaA. P1-24.

3. Press D (2010) NSA_8677_food-nanotechnology: an-overview. Nanotechnology, Science 3: 1-15.

4. Vanderroost M, Ragaert P, Devlieghere F, Bruno De M (2014) Intelligent foodpackaging: the next generation. Trends in Food Science and Technology 39: 47-62.

5. Iijima S (2007) The discovery of carbon nanotubes. Retrieved; 2007.

6. Cranford S, Yao H, Ortiz C, Buehler MJ (2009) A single degree of freedom 'lollipop' model for carbon nanotube bundle formation. J Mech Phys Solids 58: 409-427.

7. NSA_8677_food-nanotechnology--an-overview. Nanotechnology, Science and Applications

8. https://im-mining.com/2014/08/14/trials-for-potential-revolution-ofworlds-most-widely-used-man-made-product/

9. Vidu R, Rahman M, Mahmoudi M, Enachescu M, Poteca TD, et al. (2014) Nanostructures: a platform for brain repair and augmentation. Front Syst Neurosci 8: 91.

10. Nowack B, Bucheli TD (2007) Occurrence, behavior and effects of nanoparticles in the environment. Environmental Pollution 150: 5-22.

11. Kerfahi D, Tripathi BM, Singh D, Kim H, Lee S, et al. (2015) Effects of functionalized and raw multi-walled carbon nanotubes on soil bacterial community composition. PLoS ONE 10: e0123042.

12. Shrestha B, Acosta-Martinez V, Cox SB, Green MJ, Li S, et al. (2013). An evaluation of the impact of multiwalled carbon nanotubes on soil microbial community structure and functioning. J Haz Mat 261: 188-197

13. Templeton RC, Ferguson PL, Washburn KM, Scrivens WA (2006) Lifecycle effects of single-walled carbon nanotubes (SWNTs) on an estuarine meiobenthic copepod. Environ Sci Technol 40: 7387-93. 
14. Klaine SJ, Alvarez PJJ, Batley GE, Fernandes TF, Handy RD, et al. (2008) Nanomaterials in the environment: behavior, fate, bioavailability, and effects. Environ Toxicol Chem 27: 1825-1851.

15. Kang S, Pinault M, Pfefferle LD, Elimelech M (2007) Single-walled carbon nanotubes exhibit strong antimicrobial activity. Langmuir 23 8670-8673.

16. De Volder MFL, Tawfick SH, Baughman RH, Hart AJ (2013) Carbon nanotubes: present and future commercial applications. Science 339: 535-539.

17. Canas JE, Long M, Nations S, Vadan R, Dai L, et al. (2008) Nanomaterials in the environment effects of functionalized and nonfunctionalized single-walled carbon nanotubes on root elongation of select crop species. Environ Toxicol Chem 27: 19221931.

18. Kerfahi D, Tripathi BM, Singh D, Kim H, Lee S, et al. (2015) Effects of functionalized and raw multi-walled carbon nanotubes on soil bacterial community composition. PLoS ONE 10: 1-18.

19. Mukherjee A, Majumdar S, Servin AD, Pagano L, Dhankher OP, et al. (2016) Carbon nanomaterials in agriculture: a critical review. Front Plant Sci 7: 172.

20. Kappen P, Halstead B, Rider A, Pigram PJ, Brack N (2009) Multi-walled carbon nanotubes grown from chemical vapor: links between atomic near range order and growth parameters. J Phys Chem C 2009 113: 4307-4314.

21. Jones AL (1999) Post-harvest Operations. Post-harvest Compendium.

22. Broughton WJ, Hernandez G, Blair M, Beebe S, Gepts P, et al. (2003). Beans (Phaseolus spp.) model food legumes Plant and Soil 252: 55-128.

23. Chung H, Son Y, Yoon TK, Kim S, Kim W (2011). The effect of multiwalled carbon nanotubes on soil microbial activity. Ecotoxicol Environ Saf 74: 569-575.

24. Jin L, Son Y, Yoon TK, Kang YJ, Kim W, et al. (2012) High concentrations of single-walled carbon nanotubes lower soil enzyme activity and microbial biomass. Ecotoxicol Environ Saf 88: 9-15.

25. Jin L, Son Y, De Forest JL, Kang YJ, Kim W, et al. (2014). Single-walled carbon nanotubes alter soil microbial community composition. Sci Total Environ 466-467: 533-538.

26. Kang S, Mauter MS, Elimelech M (2009) Microbial cytotoxicity of carbon-based nanomaterials: implications for river water and wastewater effluent. Environ Sci Technol 43: 2648-53.

27. Khodakovskaya MV, Kim BS, Kim JN, Alimohammadi M, Dervishi E, et al. (2013) Carbon nanotubes as plant growth regulators: effects on tomato growth, reproductive system, and soil microbial community. Small 9: 115-123.

28. Husen A, Siddiqi KS (2014) Carbon and fullerene nanomaterials in plant system. J Nanobiotech 12: 16.
29. Giraldo JP, Landry MP, Faltermeier SM, McNicholas TP, Iverson NM, et al. (2014) Plant nanobionics approach to augment photosynthesis and biochemical sensing. Nat Mat 13: 400-408.

30. Miralles P, Johnson E, Church TL, Harris AT, Miralles P, et al. (2012) Multiwalled carbon nanotubes in alfalfa and wheat $囚$ : toxicology and uptake. J R Soc Interface 9: 3514-3527.

31. Srivastava A, Rao DP (2014) Enhancement of seed germination and plant growth of wheat, maize, peanut and garlic using. Euro Chem Bulletin 3: 502-504.

32. Ratnikova TA, Podila R, Rao AM, Taylor AG (2015) Tomato seed coat permeability to selected carbon nanomaterials and enhancement of germination and seedling growth. Sci World J.

33. Khodakovskaya MV, De Silva K, Biris AS, Dervishi E, Villagarcia H (2012) Carbon nanotubes induce growth enhancement of tobacco cells. ACS Nano 6: 2128-2135

34. Stampoulis D, Sinha SK, White JC (2009) Assay-dependent phytotoxicity of nanoparticles to plants. Environ Sci Technol 43: 9473-9479.

35. Eren O, Ucar N, Onen A, Kizildag N (2015) Composite Nanofibers of Polyacrylonitrile (PAN) and Amino-functionalized Carbon Nanotubes Electrospun from Dimethylsulfoxide. J Pure Appl Sci 1: 95-98.

36. Fraczek-Szczypta A, Menaszek E, Blazewicz S (2011) Some observations on carbon nanotubes susceptibility to cell phagocytosis. J Nanomat.

37. Kathi J, Rhee KY (2008) Surface modification of multi-walled carbon nanotubes using 3-aminopropyltriethoxysilane 43: 33-37.

38. In-Yup Jeon, Chang DW, Kumar NA, Jong-Beom A (2011) Functionalization of carbon nanotubes. Carbon Nanotubes - Polymer Nanocomposites 91-110.

39. Aslani F, Bagheri S, Muhd Julkapli N, Juraimi AS, Hashemi FSG, et al. (2014). Effects of engineered nanomaterials on plants growth: An overview. Sci World J 641759.

40. Khodakovskaya MV, de Silva K, Nedosekin DA, Dervishi E, Biris AS, et al. (2011). Complex genetic, photothermal, and photoacoustic analysis of nanoparticle-plant interactions. Proceedings of the National Academy of Sciences of the United States of America 108: 1028-1033.

41. Hao Y, Yu F, Lv R, Ma C, Zhang Z, et al. (2016) Carbon nanotubes filled with different ferromagnetic alloys affect the growth and development of rice seedlings by changing the $\mathrm{c}: \mathrm{n}$ ratio and plant hormones concentrations. Plos One 11: e0157264.

42. Begum P, Ikhtiari R, Fugetsu B (2000) Potential impact of multi-walled carbon nanotubes exposure to the seedling stage of selected plant species. Nanomaterials 4: 203-221.

43. Kang S, Herzberg M, Rodrigues DF, Elimelech M (2008) Antibacterial effects of carbon nanotubes: Size does matter! Langmuir 24: 6409-6413. 